\title{
CFD Simulation in Naturally Ventilated Multi-Purpose Sports Hall: Effects to the Basketball and Badminton Matches
}

\author{
M. Zofron Afif ${ }^{1}$, Sentagi S. Utami ${ }^{1}$, Randy F. Fela ${ }^{1}$, M. Kholid Ridwan ${ }^{1}$, Rizki A. Mangkuto ${ }^{2}$ \\ ${ }^{1}$ Department of Nuclear Engineering and Engineering Physics, Faculty of Engineering, Universitas \\ Gadjah Mada, Yogyakarta, Indonesia \\ ${ }^{2}$ Building Physics Research Group, Faculty of Industrial Technology, Institut Teknologi Bandung, \\ Bandung, Indonesia
}

\begin{abstract}
Minimizing the operational cost of a building while maintaining the thermal comfort is one of the criteria required in a sport facility building. However, the standard to obtain this condition in Indonesia is not yet available. The thermal comfort condition of a multipurpose sport facility in a public university in Yogyakarta, Indonesia was investigated by observing the air movement through natural ventilation openings. Performance metrics for the thermal comfort are the temperature distribution, relative humidity, air flow rate, and outdoor climate. Simulation was done using SolidWorks 2013 and the thermal condition was known. The results were compared to the Indonesia National Standard (SNI) and Design Guidance Note from Sport England. The average temperature near the arena is $30.09^{\circ} \mathrm{C}$ with relative humidity of $67 \%$, which meets the category of a comfort warm condition. The spectator seats at the tribune are considered comfortably warm. The sport hall being observed has an air change rate $(\mathrm{ACH})$ of 6.14 which exceeds the standard minimum of 1.5 and therefore, it is in no need of a mechanical ventilation system to support the air circulation.
\end{abstract}

\section{Introduction}

A sport facility is a resource that consists of a field or arena for the sport, such as a building with physical boundaries that are clearly defined and can fulfil the requirements for doing sport. Requirements are usually provided by some sport organization. A multisport building is considered a large space where air conditioning system or hybrid ventilation are commonly used to create the thermal comfort (Nishioka, Ohtaka, Hashimoto, \& Onojima, 2000). However, research on this topic are still limited, including the standards that are available to characterize the thermal comfort condition of such buildings.

In this paper, the thermal condition of the studied multisport facility is owned by a public university in Yogyakarta. The multisport facility is defined by the existence of a basketball field and three badminton fields that are often used interchangeably during sport practices. The key performance metrics of the thermal condition are the temperature distribution, relative humidity, and air flow rate, given the outdoor climate condition. A computational fluid dynamic (CFD) simulation was used for the thermal and airflow modelling using existing thermal environment data obtained from on-site measurement.

A building should provide the ability for occupants to conduct activities comfortably as optimum as possible and shelter an individual from unwanted outdoor climate conditions. Thermal comfort is a term to give information about a human being's thermal state in a given thermal environment by describing psychological, physiological, and rational approaches. Psychological approach represents the human state of mind that expresses satisfaction to the thermal environment. Physiological approach represents human's thermal perception as a result of nervous sensors from thermal receptors. Rational approach represents human body's heat balance (Enescu, 2017). Within those concepts, thermal comfort stands for the importance to provide people satisfaction, to control energy consumption, and to suggest and set standards (Taleghani, Tenpierik, \& Dobbelsteen, 2013).

To measure thermal comfort in indoor environment, several parameters (divided into personal and ambient parameters) and comfort indices have been conducted since 1890s. Personal parameters will represent the occupants' thermal characteristics, such as clothing insulation and metabolic heat rate. On the other hand, ambient parameters will represent the ambient condition, such as relative humidity, temperature, and air velocity. Other developed parameters such as dry bulb temperature, mean radiant temperature, standard effective temperature, new effective temperature, physiological effective temperature, operative temperature, globe thermometer temperature, wet bulb temperature, wet bulb globe temperature, and indoor neutral temperature.

Comfort indices for occupants developed by Fanger started with predicted mean vote (PMV) which was modified to the adaptive predicted mean vote (aPMV), extended predicted mean vote (ePMV), new predicted mean vote (nPMV), actual mean vote (AMV), predicted percentage dissatisfied (PPD), transient predicted percentage dissatisfied (TPPD), lowest possible percentage dissatisfied (LPPD), and human thermal model (HTM) (Enescu, 2017; Taleghani et al., 2013).

Researches about thermal comfort in sport facilities have been done before, specifically in gymnasiums (Al-Hababi 
\& Khalil, 2016; G. M. Revel \& Arnesano, 2014; R. M. Revel \& Arnesano, 2014), swimming pools (Lebon, Fellouah, Galanis, Limane, \& Guerfala, 2017; G. M. Revel \& Arnesano, 2014; R. M. Revel \& Arnesano, 2014), indoor tennis courts (Bugaj \& Kosinski, 2018), and multifunction sport facilities ( $\mathrm{Hu}$ et al., 2018). The standards that describes the environmental comfort criteria for a sport hall in Indonesia are still unavailable. The most common approach to predict the thermal comfort of a large space is through computer simulation based on CFD method. Various software were used for the studies above of various sport facilities, but mostly are based on CFD (Al-Hababi \& Khalil, 2016; Lebon et al., 2017).

\section{Methods}

The main method in this study is a computer simulation based on computational fluid dynamics (CFD). The software used is SolidWorks 2013 where the building geometry data can be inserted using an integrated computer-aided design (CAD) module that defines the material, sets the domain, boundary condition, meshing, and all the outputs.

\section{Description of the case studied}

The multisport building as the case study building is a building located at the sport and recreational area of the university. It is facing slightly to the northeast direction, with an open-field and a parking area surrounding the building. The north and south walls have wide area of openings for natural ventilations. These opening areas are positioned on the middle upper side of the north and south walls. All the side walls are painted-plastered bricks. The ceiling is a curved shape roof with a height approximately 15 meters and the roof is laid on an exposed truss steel structure.

The high temperature in tropical climate $\left(24^{\circ} \mathrm{C}-32^{\circ} \mathrm{C}\right)$ is not the only factor that creates uncomfortable thermal condition but also the high humidity and the very slow wind speed. A poor thermal condition may decrease working productivity. The city of Yogyakarta is a tropical humid climate with an average annual precipitation of 2,070 millimetres per year in 99 days of rain. The average temperature is $26.7^{\circ} \mathrm{C}$ and average humidity of $83.4 \%$. Tropical climate has a characteristic of a small temperature difference between daytime and night, a high air humidity at night and quite low during the middle of the day. Average air velocity during daytime in Yogyakarta is $1.0 \mathrm{~m} / \mathrm{sec}$, which is suitable for thermal comfort. Meanwhile, during rainy season the air velocity is around $2.0 \mathrm{~m} / \mathrm{sec}$.

\section{On-site Measurement}

Data for simulations were obtained from on-site measurement. The data are (1) building properties of geometry, roof shape, positions of window, glass and doors, (2) environment data of temperature, humidity, air flow rate, and solar radiation taken from 10:00 AM to 3:00 PM in the month of April 2018. The environment data used was the hottest condition in Yogyakarta during the dry season, a thermal condition that is not comfortable for sport activities. The existing conditions were taken for 7 positions. Position 1 measures the surrounding outdoor condition of the temperature, $\mathrm{RH} \%$, solar radiation. Position 2 is at located at the center of the sport arena with measurement height of $1.5 \mathrm{~m}$ above the floor for temperature and $\mathrm{RH} \%$. Position 3, 4, 5, 6, and 7 are all located at the side walls on the windows as shown in Figure 1 for measuring the air velocity. Each position represents 6 windows in the simulation model as the inlet positions. In order to comply with the computer's capability, the number of mesh for the model is 5 .

\section{Computer Simulation Settings}

For the general settings related to the analysis type, three factors where considered which are flow type using the internal flow, applying heat conduction on solid materials, and considering solar radiation in the outdoor temperature.

Radiation is defined by the sun directivity and intensity during the measurement that was done in April $5^{\text {th }}$ at noon. The building latitude is at 7.8 degrees. Using this two information, the sun elevation $\alpha$ and the sun azimuth $\Omega$ can be calculated and converted as $\mathrm{x}, \mathrm{y}, \mathrm{z}$ values with $\mathrm{x}=$ $0.116, y=0.97$, and $z=0.2$ with the sun intensity value $1074 \mathrm{~W} / \mathrm{m}^{2}$.

The type of fluid used in the simulation was the air/gas type in the default setting with turbulence flow. Materials and wall conditions were assigned in the boundary conditions setting where materials use default properties. The brick wall (outer leaf) was selected since it has the closest properties to the existing wall. The thermal condition and radiation type on the wall surfaces were using the default outer wall thermal condition with values of an adiabatic wall. Table 1 provides the descriptions of the solid materials.

Table 1: Description of Solid Materials

\begin{tabular}{|c|l|l|l|c|}
\hline No. & Elements & Material & $\begin{array}{l}\text { Radiation } \\
\text { transparency }\end{array}$ & $\begin{array}{l}\text { U-value } \\
\text { calculated } \\
\left(\mathrm{W} / \mathrm{m}^{2}{ }^{\circ} \mathrm{K}\right)\end{array}$ \\
\hline 1. & Wall & $\begin{array}{l}\text { Brickwork } \\
\text { (outer leaf) }\end{array}$ & Opaque & 2.428 \\
\hline 2. & 3 doors & Polycarbonate & Transparent & 3.184 \\
\hline 3. & 1 tribune door & Aluminium & Opaque & 3.184 \\
\hline 4. & Window & Glass & Transparent & 5.763 \\
\hline 5. & Roof & $\begin{array}{l}\text { PVC/Asbestos } \\
\text { tiles }\end{array}$ & Opaque & 2.685 \\
\hline 6. & Tribune seats & $\begin{array}{l}\text { Brickwork } \\
\text { (inner leaf) }\end{array}$ & Opaque & default \\
\hline 7. & Sport Arena & $\begin{array}{l}\text { Plywood } \\
\text { (lightweight) }\end{array}$ & Opaque & default \\
\hline 8. & Floor & Alumina & Opaque & default \\
\hline
\end{tabular}

Using the data from the existing conditions, detail of the initial conditions and the boundary conditions are then defined.

\section{Initial Conditions}

The defined parameters for the initial conditions are temperature, pressure, $\mathrm{RH} \%$, and turbulence. Temperature and $\mathrm{RH} \%$ values are based on the on-site 
measurement data. A 1 atm pressure is applied in the simulation settings. Meanwhile, the turbulence is defined by the intensity and length of the turbulence. If an inlet flow is blocked by a wall, the turbulence length scale can be predicted as 0.22 (Versteeg, H. K. and Malalasekera, $\mathrm{W})$. The turbulence level is defined by the intensity level, which in this model uses medium-turbulence case with a value of $2 \%$

\section{Boundary Conditions}

\section{- Inlet}

The inlet position is where the air enters the building through the opening window on the side walls based on the air flow rate at 5 positions (from the right to left are positions 3, 4, 5, 6, and 7) obtained from the on-site measurement as mentioned earlier. Each of this measurement positions are then applied to 6 windows that can be considered as groups of inlet positions as shown in Figure 1 using the rectangular dashed line.

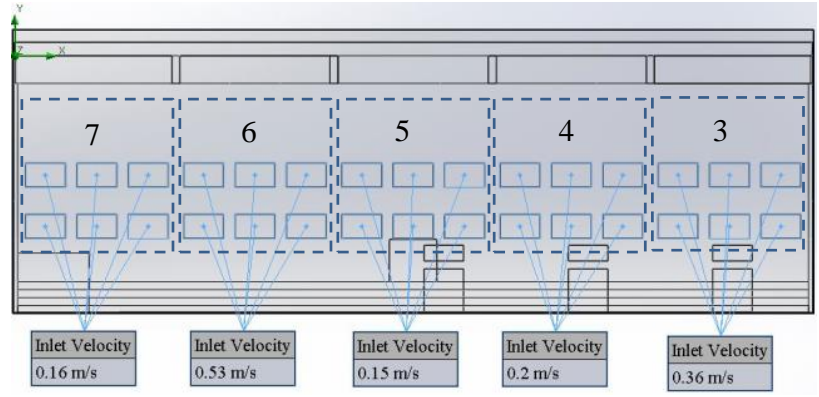

Figure 1: Inlet Position

- Outlet

Outlet is defined as openings where the air is leaving the space, positioned on the window on the roof. This boundary condition is based on the stack effect process where the air pressure will have difference vertically due to the hot temperature in the air that usually rises up, using the equation (1) (Anggoro, 2017):

$$
\Delta P=\operatorname{Cah}\left(\frac{1}{T_{o}}-\frac{1}{T_{i}}\right)
$$

Where $\Delta P$ is pressure difference $(\mathrm{Pa}), C$ is $0.0342 \mathrm{~K} / \mathrm{m}, a$ is atmospheric pressure $(\mathrm{Pa}), h$ is height $(\mathrm{m}), T_{o}$ is absolute outside temperature $(\mathrm{K})$, and $T_{i}$ is absolute inside temperature $(\mathrm{K})$. Using the stack height of $12 \mathrm{~m}$ and $\mathrm{P}_{\text {ref }}$ of $101325 \mathrm{~Pa}, \Delta \mathrm{P}=139.57 \mathrm{~Pa}$, the environment pressure defined for the outlet position is $\mathrm{P}=101185.43 \mathrm{~Pa}$ (see Figure 2).

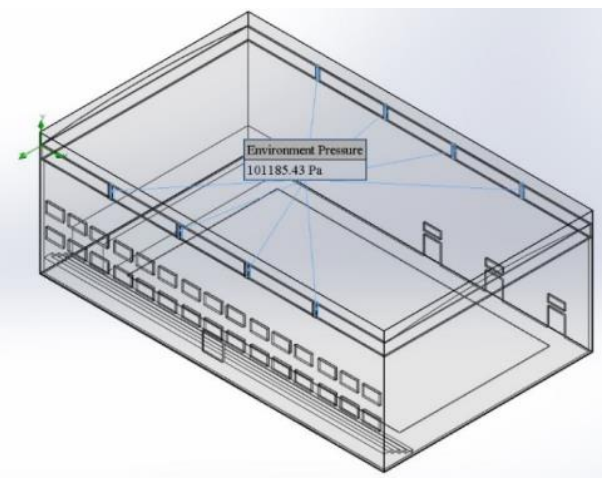

Figure 2: Outlet Position
- Wall

Wall transmission values is calculated using the equation (2) (Anggoro, 2017):

$$
U_{w}=\frac{1}{R_{\text {total }}}
$$

Where $R_{\text {total }}$ is the thermal resistance of the material, consists of the outer layer resistance $\left(R_{0}\right)$, resistance of the material $\left(R_{K}\right)$, resistance of the air on the wall surface $\left(R_{U P}\right)$, and the resistance of the air gap between the wall layers $\left(R_{R U}\right)$.

Parameters of the simulation are the temperature, humidity and air speed, which later on the data will be compared with the standard thermal comfort or standard requirement for sport facilities. Temperature and humidity distribution are taken at $1.5 \mathrm{~m}$ above ground which represents the height of a person when standing. Data were taken at 20 positions to obtain the average values of the temperature and humidity distribution of the arena (see Figure 3).

The temperature and humidity distributions are observed at the height of $0.5 \mathrm{~m}$ above the spectator tribune in order to simulate a person sitting position. This is based on the thermal comfort standard of SNI 03-6572-2001.

(Badan Standarisasi Nasional, 2001).

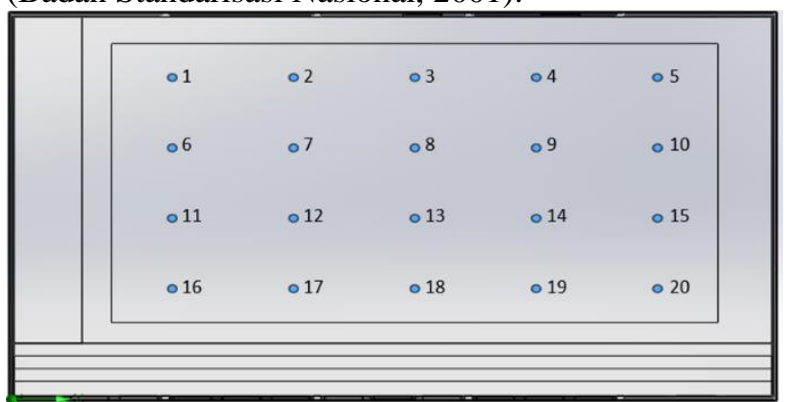

Figure 3: The 20 measurement positions on the arena.

Meanwhile, the distribution on the arena or sport field is taken 5 meters from the floor representing the area of the badminton field based on the literature of SNI 03-65722001 and badminton design guide (Sport England, 2011) (www.sportengland.com).

\section{Results}

There are several environment data obtained from the onsite measurement; temperature, $\mathrm{RH} \%$, and solar intensity data obtained from the outdoor measurement at position 1 shown in Table 2.

Table 2: On-site measurement data at position 1.

\begin{tabular}{|c|c|c|c|}
\hline Time & $\begin{array}{c}\text { Temperature } \\
\left({ }^{\mathbf{}} \mathbf{C}\right)\end{array}$ & $\begin{array}{c}\text { Relative } \\
\text { Humidity } \\
(\mathbf{\%})\end{array}$ & $\begin{array}{c}\text { Solar } \\
\text { Intensity } \\
\left(\mathbf{w} / \mathbf{m}^{2}\right)\end{array}$ \\
\hline $10: 00$ & 31.9 & 59.5 & 885 \\
\hline $11: 00$ & 32.8 & 55.7 & 978 \\
\hline $12: 00$ & 34.6 & 52 & 1076 \\
\hline $13: 00$ & 34.2 & 56.5 & 872 \\
\hline $14: 00$ & 33.3 & 59 & 635 \\
\hline $15: 00$ & 33.5 & 59.1 & 659 \\
\hline
\end{tabular}

The data in Table 2 with the data from the on-site measurement at measurement points of 2, 3, 4, 5, 6, and 7 as described earlier in the method, are used for the 
simulation. Thermal condition obtained from the on-site measurement alone is not enough to describe the thermal condition of this multipurpose sport hall due to some limitation in data collection, such as the amount of measurement points. The vertical distribution of the air temperature for instance, instead of measuring this parameter on-site, it can be predicted by running a simulation.

\section{Temperature and RH\% on the Arena}

Detail of the data for each measurement positions is described in Table 3 with the lowest temperature $29.70^{\circ} \mathrm{C}$, whilst the highest temperature is $30.29^{\circ} \mathrm{C}$. Relative humidity is in the range of between $66.26 \%$, to $68.62 \%$.

Table 3: Temperature and Relative Humidity Distribution Values

\begin{tabular}{|c|c|c|}
\hline No. & Temperature $\left[{ }^{\circ} \mathrm{C}\right]$ & Relative Humidity $[\%]$ \\
\hline 1 & 30.129 & 66.95 \\
\hline 2 & 30.071 & 67.17 \\
\hline 3 & 30.051 & 67.25 \\
\hline 4 & 30.013 & 67.39 \\
\hline 5 & 29.925 & 67.73 \\
\hline 6 & 30.143 & 66.9 \\
\hline 7 & 30.083 & 67.12 \\
\hline 8 & 30.071 & 67.17 \\
\hline 9 & 30.151 & 66.87 \\
\hline 10 & 30.054 & 67.24 \\
\hline 11 & 30.162 & 66.82 \\
\hline 12 & 30.137 & 66.92 \\
\hline 13 & 30.099 & 67.06 \\
\hline 14 & 30.157 & 66.85 \\
\hline 15 & 30.102 & 67.05 \\
\hline 16 & 30.168 & 66.8 \\
\hline 17 & 30.168 & 66.8 \\
\hline 18 & 30.112 & 67.02 \\
\hline 19 & 30.113 & 67.01 \\
\hline 20 & 30.083 & 67.12 \\
\hline Average & $\mathbf{3 0 . 1 0}$ & $\mathbf{6 7 . 0 6}$ \\
\hline & & \\
\hline
\end{tabular}

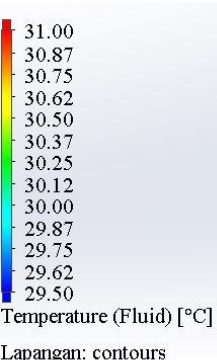

Lapangan: contours

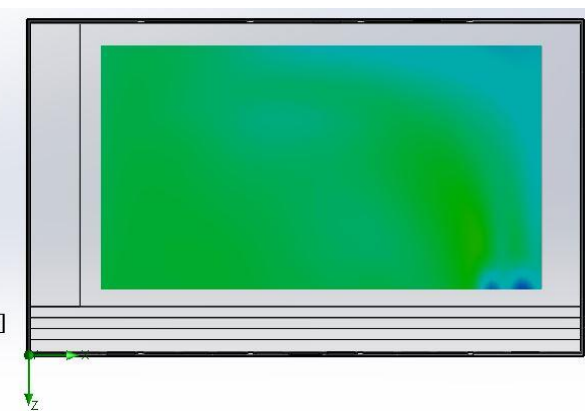

Figure 4: Plan view of the temperature contour on the sport arena.

The temperature distribution's contour of the arena as the result of the simulation is provided in Figure 4. Hence the $\mathrm{RH} \%$ distribution obtained from the simulation is illustrated in Figure 5.

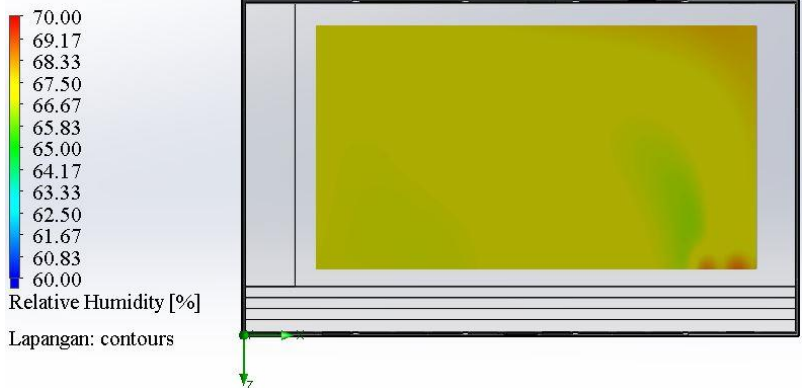

Figure 5: Plan view of the humidity contour on the sport arena.

\section{Temperature and RH\% on the Spectator Seats}

Figure 6 describes the temperature distribution's contour on the spectator seats obtained from the simulation. For the spectator seats, the temperature at the west side wall is lower than the east wall. This correlates with the data where the air speed from inlet ventilation at the west side is lower than at the east side. The lowest temperature at the West side wall is $29.61^{\circ} \mathrm{C}$, while the highest temperature is $30.3^{\circ} \mathrm{C}$, occurred at the East side wall. The lowest humidity on the West side wall is $67.22 \%$ and $61.91 \%$ on the North and South walls (see Figure 7).

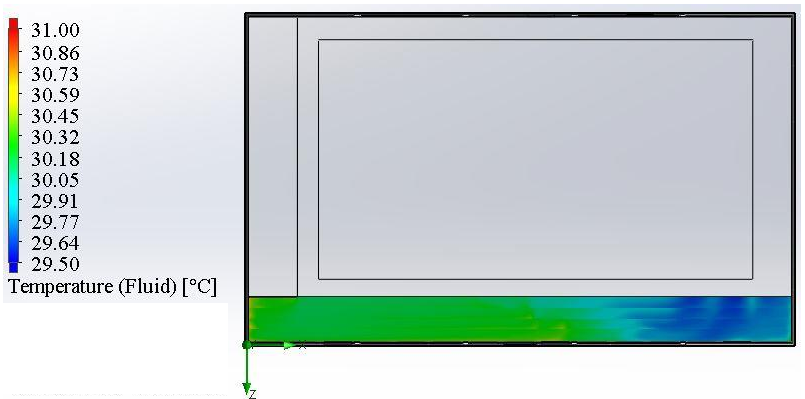

Figure 6: Plan view of the temperature contour on the

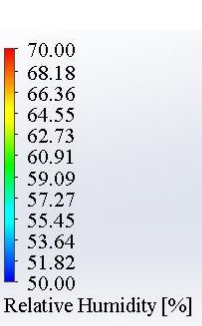
spectator seats

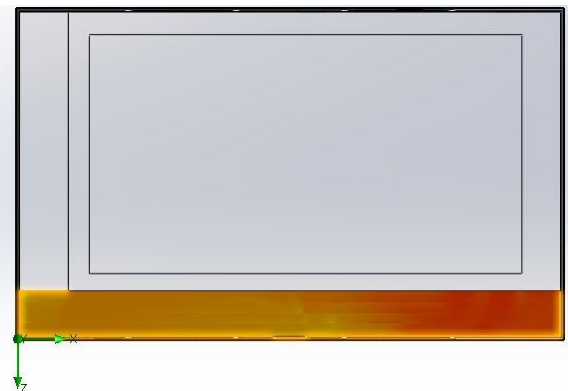

Figure 7: Plan view of the relative humidity contour on the spectator seats

\section{Discussion}

Analysis of the thermal conditions are done on two areas in the building which is the sport arena or field and the spectator seats (seats that located on a tribune).

The interval of the temperature difference on the sport arena shown in Figure 4 is as great as $0.59^{\circ} \mathrm{C}$ and the interval of the humidity difference is $2.36 \%$ as shown in Figure 5. The results indicated a uniform thermal condition on the arena or field which is a good condition in terms of thermal comfort. Average temperature and 
humidity are $30.09^{\circ} \mathrm{C}$ and $67 \%$, respectively. This thermal condition for the arena is accepted based on the criteria for an indoor temperature of a non-air conditioning building, which is ideally $26.0^{\circ} \mathrm{C}$ to $30.7^{\circ} \mathrm{C}$ (Hussein, Rahman, \& Maria, 2009). Using the Indonesia National Standard (SNI), this sport hall is categorized as a comfort warm condition.

In overall, the temperature difference on the spectator seats in Figure 6 ranges around $0.69^{\circ} \mathrm{C}$ and the humidity differences (see Figure 7) is around $5.31 \%$. These data have indicated a thermal condition of comfort warm for the spectator seats in this sport hall, as well.

Figure 8 shows the air velocity distribution on the sport field or arena. Areas mapped in read show where the air velocity exceeded $0.1 \mathrm{~m} / \mathrm{sec}$, or exceeded the maximum air velocity for a badminton match (Sport England, 2011). Therefore, given this air velocity condition, the arena is poor in serving its purpose as a badminton field. However, if the arena is used for basketball match, then due to the type of activity being performed, this arena is not providing enough air movement for cooling. In general, using the SNI standard, in order to achieve a thermal comfort condition, then the air velocity should be at least for a temperature of $27.7^{\circ} \mathrm{C}$. This means, if the room temperature is above $27.7^{\circ} \mathrm{C}$ as what seems to be happening in this sport hall, then the air velocity should be increased. From the measurement, only a few of the areas on the sport field that is experiencing air velocity up to $0.3 \mathrm{~m} / \mathrm{sec}$.

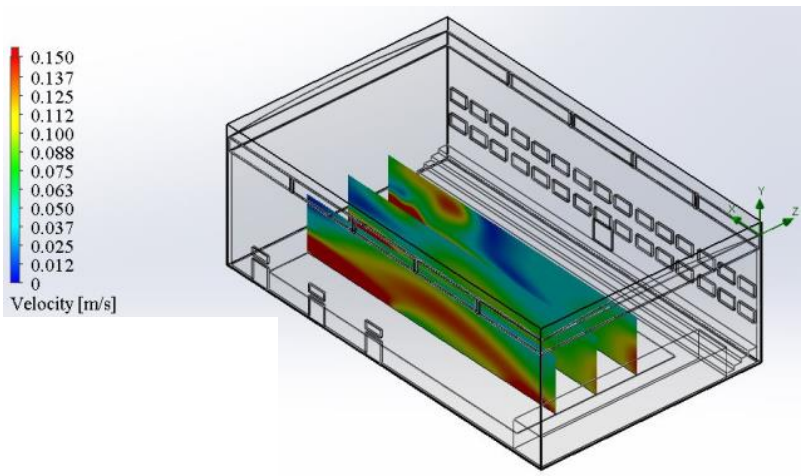

Figure 8: Air Velocity Contours on the Arena

From the discussion above, we can see that this sport hall is providing a different thermal comfort condition for two different sports. In the purpose for badminton match, the air inlet velocity needs to be reduced and vice versa for the use of basketball match.

One of the advantages of having the thermal condition simulated is that it visualizes the air movement, therefore a recommendation for further improvements can be made. For instance, if mechanical ventilation is needed in the case where the air velocity needs to be increased.

Figure 9 describes the condition where the low temperature air fills in the bottom area of the room air volume while the hot air moved up. This is what is known as the stack effect. It causes the thermal condition of a cooler air near the arena surface as compared to the upper areas (spectator seats).

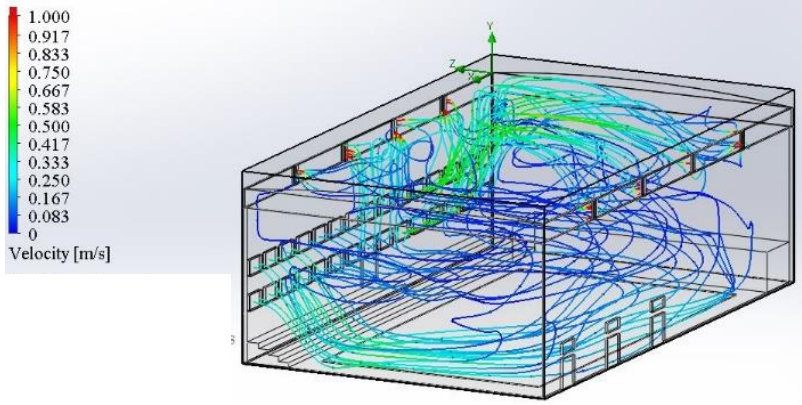

Figure 9: Air velocity distribution pattern inside the building

The simulation also provided the air changes per hour $(\mathrm{ACH})$ value of 6.14. This value is a lot larger than the minimum $\mathrm{ACH}$ required for a badminton sport facility which is 1.5 (Sport England, 2011). The results of the $\mathrm{ACH}$ value indicates that this sport hall does not require any additional exhauster for ventilation purposes.

\section{Conclusion}

The thermal condition on the indoor field during the daytime in this multisport building is described by the average temperature of $30.09^{\circ} \mathrm{C}$ and relative humidity of $67 \%$. Using the standards, it meets the comfortably warm criteria. Similar to the spectator seats that also indicated of having a comfortably warm condition.

As a multisport building, on the arena requires different air inlet velocity when it is used as basketball arena and badminton arena. The inlet ventilation should therefore apply a system that can be adjusted accordingly to the air velocity requirements in order to obtain the optimum building performance.

The air movement is actually already showing a good pattern with an $\mathrm{ACH}$ value of 6.14. This condition is one that does not quire the addition of an exhausted windows/ventilation.

\section{Acknowledgement}

The authors would like to thank the Klebengan Sport hall authorities who allowed access for on-site measurement, and to the Department of Nuclear Engineering and Engineering Physics, Universitas Gadjah Mada (UGM). We also gratefully acknowledge the support from USAID through the SHERA program - Centre for Development of Sustainable Region (CDSR). In year 2017-2021 CDSR is led by Center for Energy Studies - UGM.

\section{References}

Al-Hababi, T., \& Khalil, E. E. (2016). Numerical Investigations of Flow Patterns and Thermal Comfort in Air-Conditioned Gymnastic Sport Facility. In 54th AIAA Aerospace Sciences Meeting. San Diego, California, USA: American Institute of Aeronautics and Astronautics. 
Anggoro, S. A. (2017). Analisis Distribusi Temperatur Pada Ruang TN VII Departemen Teknik Nuklir dan Teknik Fisika UGM Menggunakan Ansys Fluent 16.2 Untuk Peletakan Rekomendasi Sensor Temperatur. Universitas Gadjah Mada.

Badan Standarisasi Nasional. (2001). Tata Cara Perancangan Sistem Ventilasi dan Pengkondisian Udara pada Bangunan Gedung. Jakarta, Indonesia: Badan Standarisasi Nasional.

Bugaj, S., \& Kosinski, P. (2018). Thermal comfort of the sport facilities on the example of indoor tennis court. IOP Conference Series: Materials Science and Engineering, $\quad 415,412024$. https://doi.org/10.1088/1757-899X/415/1/012024

Enescu, D. (2017). A review of thermal comfort models and indicators for indoor environments. Renewable and Sustainable Energy Reviews, 79, 1353-1379. https://doi.org/10.1016/j.rser.2017.05.175

Versteeg, H. K. and Malalasekera, W. (2007) An introduction to computational fluid dynamics: the finite volume method, 2nd ed. Harlow, England; New York: Pearson Education Ltd.

Hu, J., Chen, W., Zhang, S., Yin, Y., Li, Y., \& Yang, D. (2018). Thermal characteristics and comfort assessment of enclosed large-span membrane stadiums. Applied Energy, 229, 728-735. https://doi.org/10.1016/j.apenergy.2018.08.033

Hussein, I., Rahman, M. H. A., \& Maria, T. (2009). Field Studies on Thermal Comfort of Air-Conditioned and Non Air-Conditioned Buildings in Malaysia. In 2009 $3 r d$ International Conference on Energy and Environment (ICEE) (pp. 360-368). Malacca, Malaysia:IEEE.https://doi.org/10.1109/ICEENVIRO N.2009.5398622

Lebon, M., Fellouah, H., Galanis, N., Limane, A., \& Guerfala, N. (2017). Numerical analysis and field measurements of the airflow patterns and thermal comfort in an indoor swimming pool: a case study. Energy Efficiency, 10(3), 527-548. https://doi.org/10.1007/s12053-016-9469-0

Nishioka, T., Ohtaka, K., Hashimoto, N., \& Onojima, H. (2000). Measurement and evaluation of the indoor thermal environment in a large domed stadium. Energy and Buildings, 32(2), 217-223. https://doi.org/10.1016/S0378-7788(00)00048-7

Revel, G. M., \& Arnesano, M. (2014). Perception of the thermal environment in sports facilities through subjective approach. Building and Environment, 77, 12-19.

https://doi.org/10.1016/j.buildenv.2014.03.017

Revel, R. M., \& Arnesano, M. (2014). Measuring overall thermal comfort to balance energy use in sports facilities. Measurement, 55, 382-393. https://doi.org/10.1016/j.measurement.2014.05.027
Sport England. (2011). Design Guidance Note: Badminton. (J. Lee, Ed.). London: Sport England.

Taleghani, M., Tenpierik, M., \& Dobbelsteen, A. van den. (2013). A review into thermal comfort in buildings. Renewable and Sustainable Energy Reviews, 26, 201215. https://doi.org/10.1016/j.rser.2013.05.050 